\title{
RUSSIAN ORTHODOX CHURCH IN THE FIELD OF EDUCATION IN RUSSIA
}

\author{
Bogdan Ershov $^{1}$, Tatyana Vasyagina ${ }^{2}$, Natalia Osipova ${ }^{3}$, Yuri Ustinov ${ }^{4}$ \\ ${ }^{1}$ Doctor of Historical Sciences, Professor, Voronezh State Technical University, 20 years of \\ October street, 84, Voronezh, Russia, E-mail: bogdan.ershov@yandex.ru \\ ${ }^{2}$ Candidate of Sociological Sciences, Associate Professor, Associate Professor of the Department \\ of History, Moscow Aviation Institute (National Research University), MAI (NRU), Volokolamskoe \\ shosse, 4, Moscow, Russia, E-mail: tatianavas1972@mail.ru \\ ${ }^{3}$ Candidate of Sociological Sciences, Associate Professor, Associate Professor of the Department \\ of Public Administration and Social Technologies, Moscow Aviation Institute (National Research \\ University), MAI (NRU), Moscow, Russia, E-mail:nv_osipova@mail.ru \\ ${ }^{4}$ Doctor of Technical Sciences, Professor, Voronezh State Technical University, 20 years of \\ October street, 84, Voronezh, Russia, E-mail: ustinov@vgasu.vrn.ru
}

\begin{abstract}
In recent years, the problem of spiritual and moral development and education of new generations on the basis of traditional values is a matter of concern for society, which is reflected in journalism, heated public discussions, public initiative movements, current pedagogical experience, scientific and pedagogical research. The concepts of the spiritual and moral world of a person and the ways of its development that prevailed in the domestic pedagogical community in the past decades turned out to be insufficient for the pedagogical practice of social education, guided by traditional social ideals focused on the "eternal values" of altruism, social solidarity, mercy, and serving the common good. Meanwhile, the weight of these values in society is high and it is they that constitute the value basis of the constitutional system of the Russian Federation. Consequently, it is necessary to find mechanisms for the transmission of these values to new generations in the current conditions.
\end{abstract}

Keywords: church, education, society, state, people.

\section{INTRODUCTION}

In 2007, the Law of the Russian Federation "On Education" introduced provisions that determine that the result of mastering educational programs should ensure "spiritual and moral development, upbringing, the quality of training of students" (Article 9, paragraph 6), and the content of education should ensure "The formation of a spiritual and moral personality" (Art. 14, item 2).

The new Federal State Educational Standard creates conditions for the formation of mechanisms for solving these problems in the educational space of Russia. The methodological basis of the Federal State Educational Standard is the Concept of Spiritual and Moral Development and Education of the Personality of a Citizen of Russia. It determines the value-normative basis for the interaction of educational institutions with other subjects of socialization - with the family, public organizations, religious associations, institutions of additional education, culture and sports, the media. The purpose of this interaction is to jointly provide conditions for the spiritual and moral development and education of students.

The Concept indicates that the content of spiritual and moral development and education is the development of values stored in religious, ethnic, cultural, family, social traditions and passed down from generation to 
generation. They are defined as basic national values. The concept focuses on the development of the "living" reality of values that are actually woven into the socio-cultural fabric of society through the creation of an educational space of educational institutions, open to meet the current traditions of culture.

\section{DISCUSSION AND RESULTS}

The theoretical and methodological basis of the research is formed by scientific works on the problems of spiritual and moral education, development and formation of the personality in various spheres of life. Theoretical and pedagogical thought of the domestic pedagogical tradition, considering spiritual and moral education as a key element of education, presented in the works of: K.D. Ushinsky, N.I. Pirogov, P.F. Kaptereva, V.A. Sukhomlinsky and others. Historical and pedagogical issues of education are devoted to the research of such scientists as G.S. Vinsky, B.C. Bezrukova, Yu.K. Babansky, E.V. Bondarevskaya, I.A. Ilyin, V.V. Kraevsky, B.T. Likhachev, A.B. Mudrik, V.I. Slobodchikov et al. Theoretical studies of the resource value of traditions for the development of education and the ways of integrating the value systems of tradition into modern education are reflected in the works of A.Ya. Danilyuk, M.V. Zakharchenko, C.B. Zholovan, T.I. Petrakova, E.V. Shestun. In domestic science, in the works of B.S. Bratusya, F.E. Vasilyuk, A.A. Gosteva, V.P. Zinchenko, E.I. Isaeva, B.V. Nichiporova, V.I. Slobodchikova, L.F. Shekhovtsova and others consider the issues of the formation of the spiritual, value-semantic sphere of the individual as a special form of rational knowledge about the formation of the subjective spirit of a person within the limits of his individual life. Methodological developments and guidelines for spiritual and moral education in pedagogical practice are presented in the works of V.V. Abramenkova, V.A. Belyaeva.

The study has shown that the problem of interaction between the state education system and traditional religious organizations is relevant in the social, cultural, and managerial and pedagogical terms. The importance of the issues raised in the study is confirmed by events in the socio-cultural environment, in the appeal of many researchers to the search for adequate forms of spiritual and moral education of the younger generation, the introduction of the compulsory subject area "Foundations of the spiritual and moral culture of the peoples of Russia" into the basic curriculum of general education. The solution of these problems is possible with the development of interaction between the state education system and the Russian Orthodox Church as carriers of basic national values.

The study was aimed at studying the interaction of the state education system and the Russian Orthodox Church in the field of spiritual and moral education of the younger generation, the search and development of mechanisms that can include in the content of modern education the accumulated experience of the Russian Orthodox Church in the field of spiritual and moral education, confirming its effectiveness in modern conditions. Thus, the study is aimed at finding the foundations, conditions and means of harmonious, productive, fruitful cooperation between the state education system and the Russian Orthodox Church, where the basis for interaction is a single worldview, the conditions are organizational and pedagogical conditions, and the means are coordinated management mechanisms.

The theoretical and practical work carried out to study the subject of the research allowed us to confirm the well-founded hypothesis and come to the following general conclusions:

1. The essence of the modern relationship between the state education system and the Russian Orthodox Church is coordinated, jointly distributed activities to develop common ideas about the basic meanings of modern education, about the spiritual and moral formation of the individual, about the worldview foundations of modern domestic education and the national educational ideal, as well as about building educational practice, in which the system of relationships of the individual to society, the state, the church and to the individual is laid.

2. The content of the interaction between the state education system and the Russian Orthodox Church is currently the implementation of jointly developed ways and means of introducing into the content of modern education the experience of spiritual and moral education of the younger generation, accumulated in the Orthodox tradition.

3. The process of interaction between the state education system and the Russian Orthodox Church is ensured in compliance with the following principles:

- The unity of the meanings and goals of spiritual and moral education;

- General understanding of the content of spiritual and moral education;

- Respectful attitude to the experience accumulated by the parties in this area and to the cultural and historical traditions of interaction between the Russian Orthodox Church and the education system in Russia; 
- Observance of the principle of sovereignty in the activities of the state education system and the Russian Orthodox Church.

4. The general mechanism for the implementation of the system of potentially possible interactions between the state education system and the Russian Orthodox Church in the field of spiritual and moral education of the younger generation is a functional model of their jointly-coupled and jointly-distributed activities, which includes the main, supporting functions: organizational and managerial , regulatory, scientific, methodological and project-program, innovative structure, as well as organizational and pedagogical conditions: reliance on cultural and historical experience, organization of collective activities, distribution of powers and responsibilities, responsibility for the result.

The Russian Orthodox Church unites a multimillion-strong family of Orthodox peoples and maintains continuity with a two thousand year old Eastern Christian cultural tradition.

The civilizational choice of the holy Equal-to-the-Apostles Prince Vladimir, who introduced Russia to the Orthodox faith, for many centuries secured a special educational role for the Russian Church throughout the entire space of historical Russia. Many holy ascetics, teachers of morality and spirituality, great cultural and artistic figures, military leaders and heroes, people who determined the course of national history in different epochs were brought up by the Russian Church.

Thanks to the educational and enlightening ministry of the Church, the light of Christ enlightened many peoples who became Christian not only by faith, but also by culture. With the participation of the Church, the first schools were created in Russia. Thanks to the Church, chronicles developed, under the auspices of the Church, extensive translation activities were carried out, the Church stood at the origins of book publishing. After the emergence of the system of secular education, the Church actively interacted with it. Even in the conditions of growing secularization, theological and parish schools adequately fulfilled their Christian educational vocation.

The post-revolutionary period became a time of harsh suppression of Orthodoxy by the atheist state and anti-religious social forces, the expulsion of the Church from social and cultural life. The persecution of the Church has fully affected the educational sphere as well. All pre-revolutionary theological academies and seminaries of the Russian Church were closed in the 1920s, and only in the post-war period was the Church allowed to restore its educational potential to a very limited extent.

However, even in conditions of direct persecution, the Church continued to fulfill its educational mission to the extent that it was possible in conditions of external lack of freedom.

The development of theological science continued in the diaspora, where theological educational institutions were founded, which educated a whole galaxy of outstanding scientists and church leaders. Finding themselves in a non-Orthodox environment, Orthodox theologians entered into a creative dialogue with scholars who belonged to other Christian confessions. Largely thanks to the figures of the Russian emigration, Orthodox theology gained fame in the West. For the Russian-speaking diaspora itself, the development of theological education has become one of the factors in the preservation of its religious and cultural identity.

The change in the state structure in the countries of the canonical presence of the Russian Orthodox Church at the end of the twentieth century opened up opportunities for a qualitative expansion of the Church's activities in the field of enlightenment, education and science. The Church created new theological educational institutions, and theology began to gradually return to university education as an integral part of human knowledge. Theological science received a new impetus for its development.

The life of the Russian Church is being revived in the conditions of a post-atheistic, secular era, which determines the content of the new challenges facing the Church in the educational sphere. The atheistic ideology that prevailed in the previous period left behind a heavy legacy, which is exacerbated by the influence of consumerist ideology, the crisis of the family and the destruction of ties between generations. The world outlook and spiritual crisis has largely affected the education sector, threatening its degeneration into "educational services" devoid of spiritual aspirations and educational functions.

In these conditions, the Church sees its duty to contribute to the return to society of the lost Orthodox cultural and religious values, including through various forms of upbringing and education aimed at the formation of a spiritual and moral personality, a citizen of the Fatherland, as well as understanding that educational activities are not can be exclusively applied, professional in nature, without affecting the moral, educational and worldview dimensions. At the beginning of the 21st century, the treasures of theological, historical, and cultural tradition, accumulated by the Russian Church, and its spiritual and moral ideals, are again in 
demand.

\section{CONCLUSION}

The construction of effective interaction between the state education system and the Russian Orthodox Church on the basis of jointly distributed activities contributes to overcoming disagreements and confrontation and the transition in a significant number of cases to the level of constructive relationships, which presupposes scientifically organized social partnership, dialogue and cooperation.

The conducted research has confirmed the correctness of the hypothesis. The goal of the study has been achieved, the tasks have been solved.

\section{REFERENCE LIST}

Bulanova M. V. (2004) Pedagogy and psychology of higher education: textbook. stipend. Rostov-on-Don: Phoenix. 544 p. (in Russ).

Chekmeneva T.G., Ershov B.A., Trubitsyn S.D., Ostapenko A.A. (2020) Chinas Information Security Strategy: Political and Technical Aspects. Bulletin Social-Economic and Humanitarian Research. Volume 7. Number 9. Pp. 78 - 97. doi: 10.5281/zenodo.3911320 (in Russ).

Ershov B.A. (2010) The Russian Orthodox Church and secular power in the Voronezh province in the XIX early XX centuries. GOU VPO "Voronezh State Technical University". Voronezh. 167 p. (in Russ)

Ershov B.A. (2010) The system of spiritual education in Voronezh province in the 19th century. Education and Society. №. 5 (64). Pp. 105-108. (in Russ).

Ershov B.A., Fursov V.N. (2018) The Russian Church in the State Mechanism of Russia. Bulletin SocialEconomic and Humanitarian Research. № 1. Pp. 32-37. (in Engl).

Ershov B.A., Perevozchikova L.S., Romanova E.V. (2019) Globalization and Intensification of Spiritual Values in Russia in the Philosophical Aspect. 6th International Conference on Education and Social Sciences Abstracts \& Proceedings. Pp. 208-212. (in Engl).

Ershov B.A., Perevozchikova L.S., Romanova E.V., Ashmarov I.A. (2019) The Concept of Spirituality in Social Philosophy. Smart Innovation, Systems and Technologies. T. 139. Pp. 688-694. (in Engl).

Finogentov V. (2011) The worldview component of education. Common Sense. №. 3 (60). Pp. 12-20. (in Russ).

Kukushkina E. I. (1989) Worldview, cognition, practice. Moscow: Politizdat. 303 p. (in Russ).

Leontiev A. N. (2004) Activity. Conscience. Personality. M.: Smysl; Akademiya. 352 p. (in Russ).

Makarenya A. A. (1997) Cultural environment: status, structure, functioning. Tyumen: TOGIRRO. 65 p. (in Russ).

Pirogov N. I. (2008) Questions of life. The diary of an old doctor. Ivanovo. 427 p. (in Russ).

Rapov, O. M. (1988) The Russian Church in the IX first third of the XII century. Adoption of Christianity. M. Higher School. 416 p. (in Russ).

Sakharov A.M. (1969) Education and development of the Russian state in the XIV-XVII. M. Higher School. 223 p. (in Russ).

Slastenin V. A. (2002) Pedagogy. studies. manual for students. higher. ped. ucheb. institutions. M. Academy. 576 p. (in Russ).

Sukhomlinsky V. A. (1979) Problems of education of a comprehensively developed personality. Kiev: Radyansk school. $686 \mathrm{p}$.

Znamensky P. V. (2001) Spiritual schools in Russia before the reform of 1808. St. Petersburg: Summer Garden, Kolo. 800 p. (in Russ).

Perevozchikova L. S., Ershov B. A., Ashmarov I. A., Volkova E. A. (2017) Role of Russian orthodox church in life of peasants in Russia in XIX - the beginning of the XX-th centuries. Bylye gody. Russian Historical 
Journal. №. 43 (1). Pp. 121-128. (in Russ).

Shkarubo S.N. (2019) The nobility of the Russian empire in the XIX century: rights and duties. Bulletin Social-Economic and Humanitarian Research. №. 1 (3). Pp. 43-48. (in Engl).

Shkarubo S. N. (2019) Main directions in the policy of Nicholas I on the solution of the peasant question: historiography of the problem. Modern science: actual problems of theory and practice. Series: Humanities. №. 1. Pp. 48-51. (in Russ). 